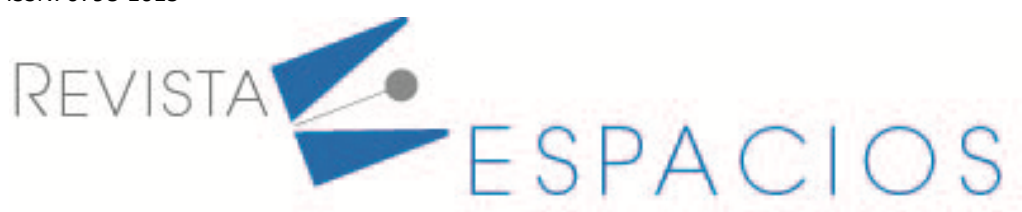

\title{
Methodological approach to managing industrial enterprises while implementing labor productivity projects
}

\section{Enfoque metodológico de la gestión de empresas industriales en la implementación de proyectos para el crecimiento de la productividad laboral}

\author{
POPOV, Viktor L. ${ }^{1}$ \\ ALEXANDROVA, Tatyana V. ${ }^{2}$
}

\begin{abstract}
Analysis of issues related to labor productivity projects at Russian enterprises showed that the research mostly focus on identifying ways for increasing business productivity, but not on how organizational management fundamentals influence performance targets. Therefore, applying an integrative approach, the authors investigate the possibilities of transforming the management of enterprises that implement projects to increase labor productivity. An integrative model of enterprise management has been developed and tested in practice, which ensures a higher growth of labor productivity.

key words: labor productivity, system-based approach to management, process-based approach to management, integration

Resumen

Un análisis de proyectos para aumentar la productividad laboral en las empresas rusas mostró que la investigación se centra principalmente en identificar formas de aumentar la productividad empresarial, en lugar de estudiar el impacto de la gestión en los objetivos de desempeño. Aplicando un enfoque integrador, los autores exploran las posibilidades de mejorar la gestión en proyectos para aumentar la productividad laboral. Se ha desarrollado y probado en la práctica un modelo integrador de gestión empresarial, que asegura un mayor crecimiento de la productividad laboral.

Palabras clave: productividad laboral, enfoque sistemático de la gestión, enfoque de procesos para la gestión, integración
\end{abstract}

\section{Introduction}

The current state of the Russian economic system predetermines the relevance of searching and implementing new tools for increasing labor productivity at domestic enterprises. Currently, the output per worker in Russia is only $\$ 23$ per hour. In developed countries, this figure is 2-3 times higher. The Russian Federation laggs behind the $\mathrm{G} 7$ countries in terms of labor productivity by 40 years (Report, 2019). Bridging the gap in labor productivity between Russia and developed countries is becoming an important state task. In order to solve it the President

\footnotetext{
${ }^{1}$ Doctor of Technical Sciences, Professor. Department of Management and Marketing. Perm National Research Polytechnic University. pku06@mail.ru

${ }^{2}$ Candidate of economic sciences, Associate professor. Department of management. Perm State National Research University. atvpsu@yandex.ru
} 
of the Russian Federation initiated the national project "Labor productivity and employment support" (Passport, 2019).

The national project "Labor productivity and employment support" is a priority for the country for the period from 2019 to 2024, since its implementation contributes to the growth in efficiency of resource utilization, modernization of production, stimulation of innovation and export activities at industrial enterprises in nonresource sectors of the economy. The project is aimed at achieving an increase in labor productivity of at least $5 \%$ per year. The reason for this growth should not be an increase in the volume of investments, but the mobilization of the enterprise's development reserves (Passport, 2019). In 2019, the project participants included 768 domestic enterprises from 36 regions of the Russian Federation; by 2024, this figure must reach at least 10,000 participants from 85 regions (Report, 2019).

The national project "Labor productivity and employment support" is a complex one and requires developing measures to innovatively transform various areas of the enterprise. While implementing it, the participating enterprises initiate and put into practice various corporate projects aimed at ensuring a targeted increase in labor productivity.

\subsection{Urgency of the research}

In 2019 the results of implementing the national labor productivity project has shown that, as a rule, the participating enterprises strive to solving applied problems. These include determining directions for improving production activities; training the personnel; defining a pilot project; forming a team of reformers; making the necessary changes; and, replicating the results, if they are successful. The implemented changes often do not touch upon fundamental issues related to improving enterprise management. As a result, difficulties arise. They are connected with putting into practice the planned measures to transform the existing business and the implementation of the national project's target parameters at the level of individual enterprises.

There is a problem of improving the management quality at enterprises participating in the national labor productivity project. This problem is largely due to the peculiarities, connected to the study and application of basic approaches to management, which prevail at industrial enterprises. In the managerial practice two approaches to enterprise management are traditionally considered independently: the system-based approach and the process-based one. Despite the fact that this division is rather arbitrary, the autonomous application of each of them gives different results. The system-based approach, formed at the beginning of the XX century, is based on the concept of "management function" and leads, as a rule, to the construction of a linear-functional organizational structure of management. The process-based approach, formed in the 70-80s of the last century and based on the concept of "process", places this concept above the "management function", which ultimately leads to the need to transform the previously existing hierarchical management structures. This transformation should be directed to creating flat-oriented organizational management structures (project groups, working cells, etc.).

The process-based approach to enterprise management is often used as a means of improving performance within the national labor productivity project (Kirchmer, 2017). Its application is expected to solve many of the company's current problems: reducing costs, increasing profitability, entering new markets, increasing output, expanding the scale of business, etc. It is these expectations that explain the dominance of the process-based approach to management when carrying out organizational changes within the project "Labor productivity and employment support ". At the same time, the system-based approach has far from exhausted its potential in terms of improving the activities of the enterprise involved in the national project. It has the ability to integrate various components that support the operation of an enterprise, orienting them towards the overall goal of the system - increased productivity (Pulakos, 2009). In this regard, this article attempts to integrate the 
methodological elements of the system-based and process-based approaches for improving the manageability of an enterprise in the national project "Labor productivity and employment support".

\subsection{Literature review}

The analysis was carried out to study the possibilities of improving management at the enterprises participating in the national project. This analysis comprised the applicable regulatory and methodological documents and existing publications in regard to the implementation of the national project "Labor productivity and employment support".

The Federal Competence Center for Increasing Labor Productivity developed some recommendations for improving the management at enterprises participating in the national project (Methodical recommendations, 2019). In particular, it singles out the mandatory components, which should be implemented in the field of management. They include decomposition of goals; production flow management; project and change management; development of motivation for transformation and involvement of employees in the transformation processes at the enterprise. This presupposes a significant transformation of the business processes operating at enterprises. Also, much attention is paid to the introduction of the "lean manufacturing" concept, which has high expectations in terms of increasing labor productivity at enterprises. At the same time, the recommendations of the Federal Center of Competence do not emphasize the rationale for using the tools of quick-response and active production to manage the growth of labor productivity. They also do not consider the possibility of integrating various approaches to management development. Moreover, these recommendations do not offer specific directions for improving the management systems operating at enterprises.

Currently foreign and domestic scientists are actively studing the application of an integrative approach to enterprise management: Best K. (2006), Sherman D. J., Berkowitz D. \& Souder, E. W. (2005), Yu D. \& Zhou R.(2017), Zollo M., Minoja M. \& Coda V. (2018), Parfenova M.Ya. (2013), Badalov A. YU., Dudnikov A. S. \& Trubicyn S. N. (2011). These research results present an undoubted interest for domestic enterprises, but they are not adapted to the specifics of the national project "Labor productivity and employment support" implementation.

As for publications, which study problematic aspects associated with the implementation of the national labor productivity project in Russia, they often indicate the need to transform the existing management practice in order to quickly master effective methods for increasing labor productivity. This problem is emphasized in the works of Ivanov O. B. \& Buchwald E. M. (2019), Kostareva L.V. (2018), Rusanovskiy V.A. \& Markov V.A. (2017), Radosteva M. V. (2018), Dolzhenkova Yu. V., Polevaya M.V. \& Kamneva Ye. V. (2019). The disadvantage of this kind of research is that they do not provide specific recommendations for improving management at enterprises that are involved in the labor productivity projects.

Analysis of available publications and regulatory and methodological materials showed that present studies do not give a full understanding how to improve management based on the integration of various approaches to enterprise management and how this can influence the productivity growth. The analysis also showed that there are no specific recommendations how to use an integrative approach to management for enterprises participating in the national labor productivity project.

\subsection{Research goal and tasks}

The purpose of the study is to use the possibilities of an integrative approach to enterprise management to achieve the goals of the national project "Increasing labor productivity and supporting employment" more effectively. The goal of the research was achieved by solving the following tasks: 
- Conducting a comparative analysis of the system-based and process-based approaches to enterprise management in relation to the participants of the national labor productivity project;

- Allocating the main groups of processes associated with the basic elements of the enterprise management system in the framework of the national labor productivity project;

- Developing an enterprise management model based on the integration of system-based and process-based approaches, which creates conditions for the implementation of labor productivity projects.

\section{Methodology}

The recommendations of the Federal Center of Competence in the field of increasing labor productivity were used as a regulatory and methodological basis for the research. In theoretical terms, the study is based on the scientific works of Russian and foreign authors studying approaches to integrating various areas of management and solving problems related to the implementation of labor productivity projects. The practical information required for the study was provided by the Regional Center for Labor Productivity Competence, an autonomous non-profit organization of Perm Krai.

The study used expert and analytical information from the report of the Accounts Chamber of the Russian Federation, which resulted from monitoring the progress of the national labor productivity project in 2019 (Report, 2019).

The monitoring results of the Accounts Chamber of the Russian Federation show that in 2019 the potential of the national project "Labor productivity and employment support" was not fully realized. 21 out of 36 regions participating in the project could not achieve the target project indicators. The national project contributed only $12 \%$ into the achievement of the key strategic goal of the country's socio-economic development. This goal implies "the Russian Federation entry into the world's 5 largest economies and ensuring economic growth rates higher than the world". A selective analysis, which looked at the activities of 252 enterprises out of 768 participants in the national project, showed that different problems arise in the process of achieving the goals of corporate labor productivity projects. The most common problems include training personnel, developing new products, organizing product flows, expanding the sales market and developing exports (Report, 2019 ). This indicates that individual processes and management functions are developed insufficiently. The survey results show that among managers of 200 enterprises implementing labor productivity projects, $48 \%$ rated the effectiveness of these projects as high, $28 \%$ rated it as average, $12 \%$ rated it as low (Report, 2019).

Two research hypotheses were formulated based on the analysis, which delt with the implementation process of labor productivity projects at Russian industrial enterprises:

1. The labor productivity at enterprises can be significantly increased using an improved management model adapted to the specifics of implementing labor productivity projects.

2. If the improved management model is put into practice in the labor productivity projects, it will lead to improved results of management activities of the enterprise as a whole.

The research applied the methodology of an integrative approach to solving management problems. The research is based on the core type of the management areas integration at industrial enterprises, aimed at a more efficient implementation of the national project's "Labor productivity and employment support" target parameters. Also, the study uttilized the methods of systemic and comparative analysis, the methodology for identifying active business processes developed by the International Benchmarking Clearinghouse (APQC, 2019). 


\section{Results}

Both system-based and process-based approaches to management are traditionally used in the current practice of implementing the national labor productivity project at industrial enterprises. Table 1 presents typical advantages and disadvantages, which become obvious when applying system-based and process-based approaches to the management of organizational changes within this national project (Table 1).

Table 1

The comparison between system-based and process-based approaches when conducting organizational changes at enterprises while implementing the national labor productivity project

\begin{tabular}{|c|c|c|}
\hline $\begin{array}{l}\text { Approach to } \\
\text { managemant }\end{array}$ & Advantages & Disadvantages \\
\hline System-based approach & $\begin{array}{l}\text { - Common idea of management; } \\
\text { - Good structuring; } \\
\text { - Considerable application experience at } \\
\text { enterprises }\end{array}$ & $\begin{array}{l}\text { - System changes often lead to } \\
\text { the need of re-engineering; } \\
\text { - High probability of staff } \\
\text { pushback }\end{array}$ \\
\hline Process-based approach & $\begin{array}{l}\text { - Good presentation logic; } \\
\text { - Smoothness of change when it is } \\
\text { necessary to improve management; } \\
\text { - Good opportunities for managemant's } \\
\text { digital transformation }\end{array}$ & $\begin{array}{l}\text { - As a rule, prevails at factory } \\
\text { workshop's level (the level of } \\
\text { structural divisions); } \\
\text { - High probability of managers } \\
\text { pushback when attempting } \\
\text { change }\end{array}$ \\
\hline
\end{tabular}

Source: authors' elaboration

Both approaches are well developed theoretically and, due to their merits, can potentially make a significant contribution to achieving the goals of the national labor productivity project at the level of individual enterprises. But their inherent disadvantages do not always allow to realize their initial potential in the practice of organizational change to the full extend. It is necessary to choose a combination of management areas relevant to the implementing practice of the national project "Labor productivity and employment support" at industrial enterprises in order to resolve this contradiction within the core integration aimed at increasing labor productivity.

\subsection{Specific implementation features of system-based and process-based approaches to managing an enterprise while putting into practice labor productivity projects}

Figure 1 (Fig. 1) shows a conceptual management scheme of an enterprise participating in the national labor productivity project in Russia. This diagram (Fig. 1) reveals that the enterprise management system posseses the elements characteristic of both the system-based approach (hierarchy and management functions) and the process-based one (business processes that need to be managed) in various amounts. However, initially, there is no identification of the groups of processes that affect the construction of the organizational management structure and form the most significant interdependencies within the management system of the enterprise participating in the national project. 
Figure 1

Conceptual diagram of the management system at an enterprise participating in the national project "Labor productivity and employment support"

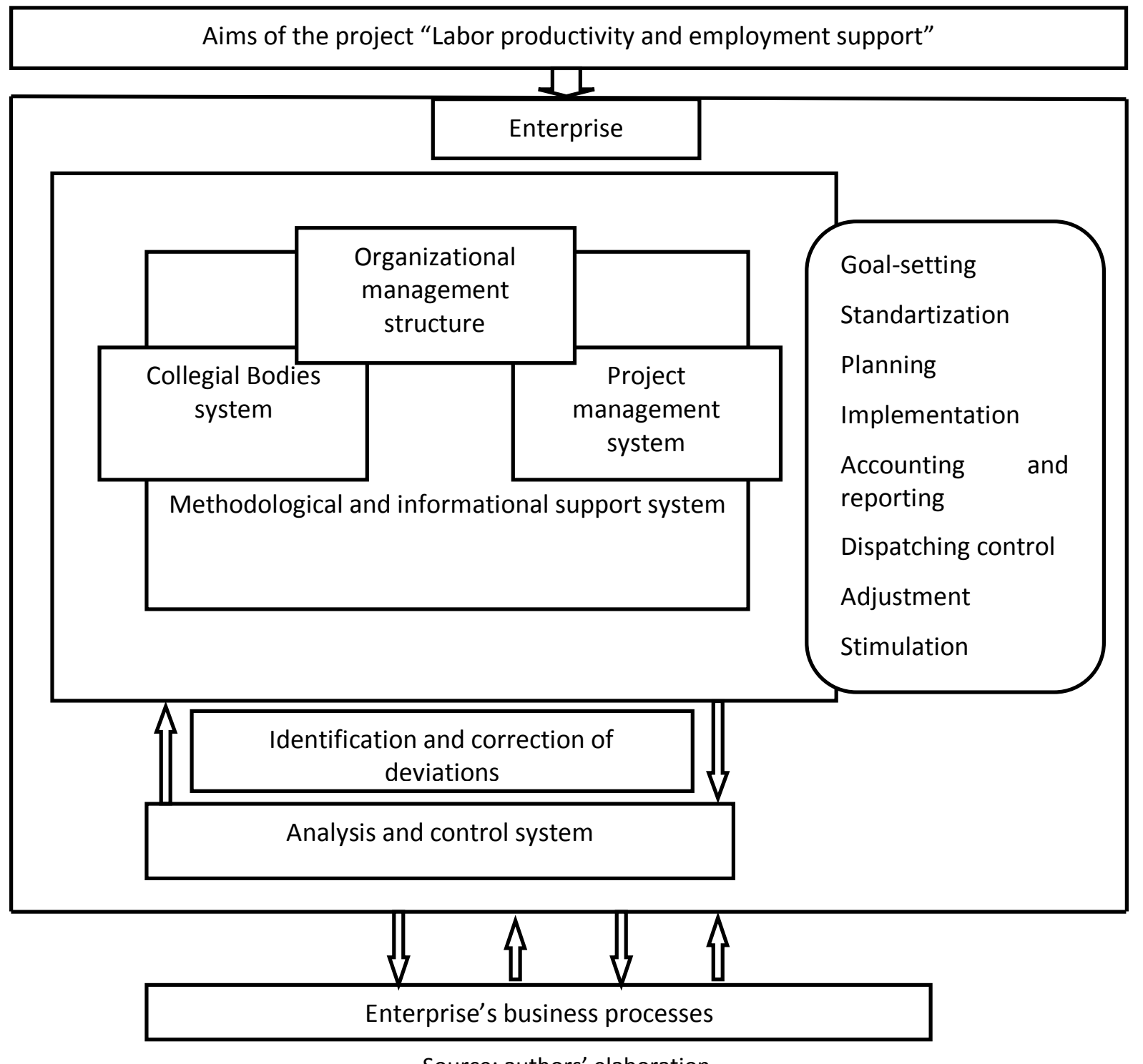

Source: authors' elaboration

The list of processes by the International Benchmarking Clearinghouse (IBC) (APQC, 2019) was used as a methodological basis for identifying the processes that are most significant for improving enterprise management in labor productivity projects. In accordance with the specified list, 13 groups of active processes are distinguished (Fig. 2) that affect the efficiency of the enterprise. 
Figure 2

Groups of active IBC processes used to improve management at enterprises participating in the national project "Labor productivity and employnment support"

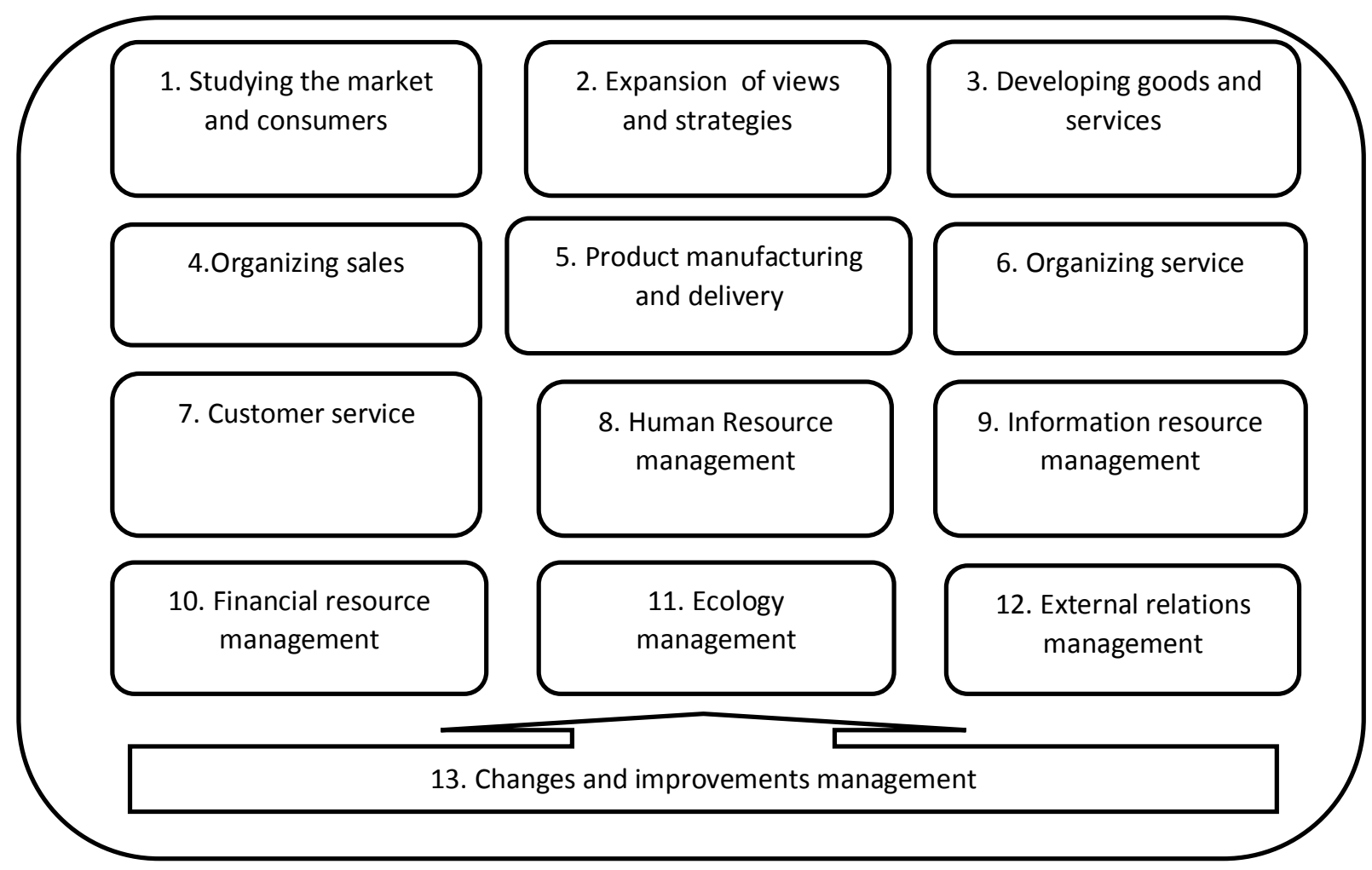

Source: developed by the authors based on (APQC, 2019)

Practice shows that among the IBC processes groups presented in Fig. 2, three processes influence the most significantly on the formation of an enterprise management system when introducing the national labor productivity project:

- Process "Expansion of views and strategies" with sub-processes "Development and establishment of enterprise goals" and "Development of the organizational structure and relationships between organizational units";

- Process "Human Resource Management" with sub-processes "Development and training of personnel" and "Ensuring involvement";

- Process "Changes and improvenments management" with sub-processes "Improvement of processes and systems" and "Assessment of the enterprise performance ".

One of the recent achievements, demonstrated by a system-based approach to enterprise management, is forming and practicing three effective types of production systems: LEAN (lean manufacturing) (Hobbs, 2007), QRM (quick-response manufacturing) (Suri, 2015) and Agile (active manufacturing) (Con, 2019). Table 2 (table 2) presents the structured information on the application peculiarities of new production systems at industrial enterprises in the conditions of the national project "Labor productivity and employment support". Three of the seven characteristics formed in the $7 \mathrm{~S}$ concept ( Gokdeniz \& Kartal, 2017) are taken as production systems identification indicators, namely: strategy, structure, personnel. 
Table 2

Main characteristics of production systems, which have a perspective

for application in the implementation of the national labor productivity project

\begin{tabular}{|l|l|l|l|}
\hline \multicolumn{1}{|c|}{ Name of the system } & \multicolumn{1}{|c|}{ Strategy } & \multicolumn{1}{c|}{ Structure } \\
\hline $\begin{array}{l}\text { LEAN - lean } \\
\text { manufacturing }\end{array}$ & $\begin{array}{l}\text { Systematic application } \\
\text { of TOYOTA tools to } \\
\text { reduce costs }\end{array}$ & $\begin{array}{l}\text { Linear-functional, } \\
\text { matrix and product }\end{array}$ & $\begin{array}{l}\text { Each employee is an active participant } \\
\text { in kaizen transformations }\end{array}$ \\
\hline $\begin{array}{l}\text { QRM - quick-response } \\
\text { manufacturing }\end{array}$ & $\begin{array}{l}\text { Minimization of lead } \\
\text { time if the production } \\
\text { has a reserve margin }\end{array}$ & $\begin{array}{l}\text { Self-goverened } \\
\text { production units }\end{array}$ & $\begin{array}{l}\text { Production unit members interested in } \\
\text { teamwork results }\end{array}$ \\
\hline $\begin{array}{l}\text { Agile - active } \\
\text { manufacturing }\end{array}$ & $\begin{array}{l}\text { Ensuring a high rate of } \\
\text { change, focus on } \\
\text { developing unique } \\
\text { products }\end{array}$ & $\begin{array}{l}\text { Network structures, } \\
\text { project teams }\end{array}$ & $\begin{array}{l}\text { The core of the company is a highly } \\
\text { qualified permanent staff. Temporary } \\
\text { personnel are recruited according to } \\
\text { the situation. }\end{array}$ \\
\hline
\end{tabular}

Source: authors' elaboration

Choosing a concept for the production system development represents a very important stage in the implementation of the national project at a particular enterprise. The LEAN concept is the most popular today. It is this concept that the Federal Competence Center recommends as a basis for transforming the production system at enterprises participating in the national project. The undoubted advantage of the LEAN concept is the versatility of the tools used in it. No one needs to be convinced that it is necessary to strive for the utmost reduction of unnecessary costs. The situation is more complicated if the enterprise manufactures one-off products. In this case, the most rational decision is to apply the QRM concept, where the success criterion is the lead time for a specific order. However, the transformation of the production system using QRM principles requires:

- abandoning the power hierarchy and moving to a flat-oriented management structure;

- having a stock (up to 20\%) of temporarily idle equipment;

- ensuring the system dynamics of people, equipment and processes.

Implementation of the Agile concept is no less difficult. First, its use presupposes that the majority of the enterprise's key personnel have strategic management competencies; secondly, the stereotype dominates that it is suitable only in the field of information technology. Therefore, in the case of applying the QRM and Agile concepts, people need to be explained the obvious benefits of these innovations, employees should be actively trained in new methods of work and their involvement in innovative processes should be increased in order to avoid staff pushback.

\subsection{Intergative approach to enterprise management}

The authors proposed an integration model of system-based and process-based approaches to enterprise management within the national project "Labor productivity and employment support", presented in Figure 3 (Fig. 3). This model is based on the elements of the management system conceptual diagram presenting enterprises participating in the national project (Fig. 1). The second basis is formed by the selection of the processes from the list of IBC (Fig. 2) which have the most significance for the success of the national project and the application of promising concepts for the development of production systems (Table 2). 
Figure 3

Integration model of system-based and process-based approaches to managing an enterprise participating in the national labor productivity project

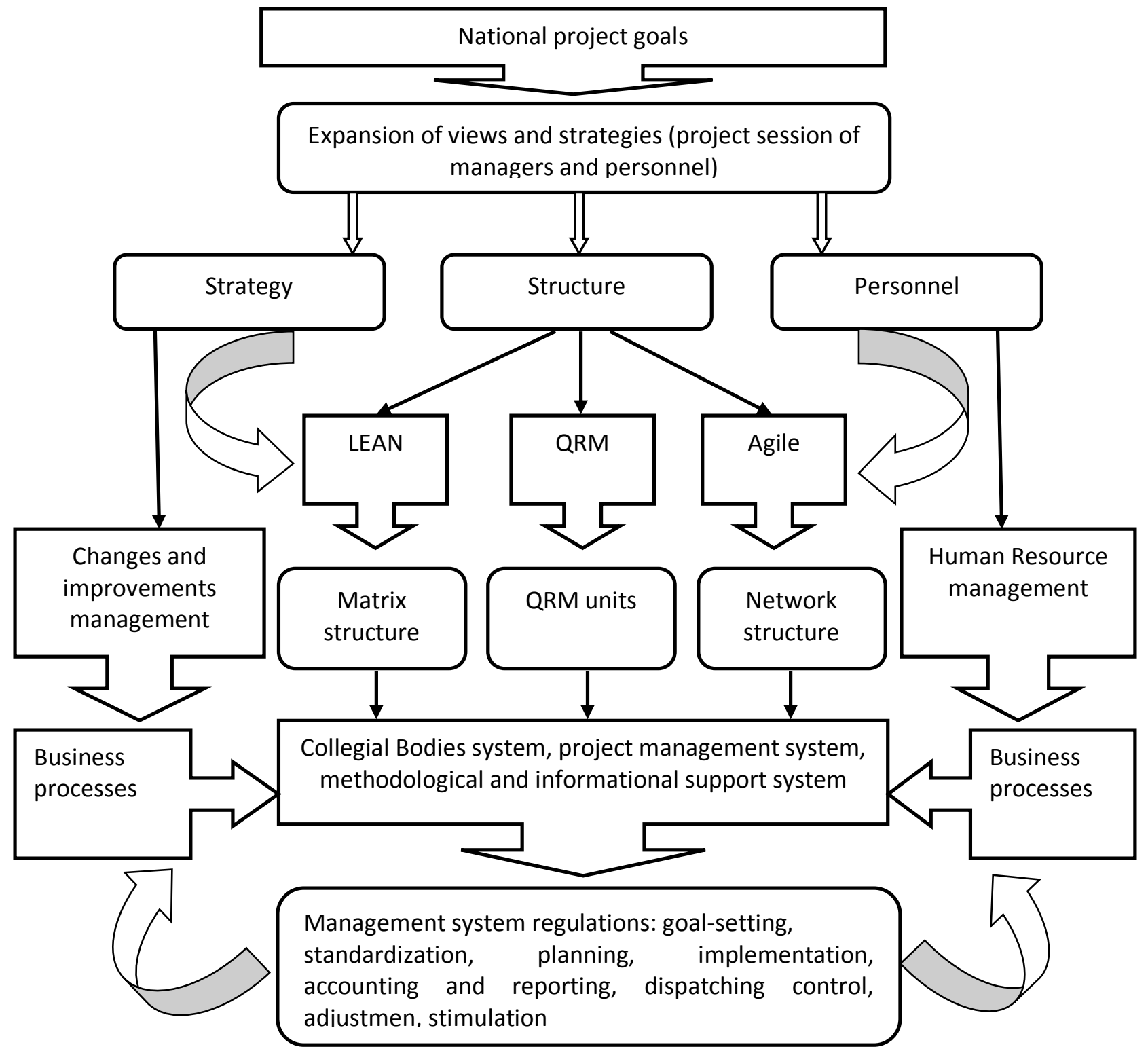

Source: authors' elaboration

The proposed model (Fig. 3) complies with the requirement of the methodological recommendations by the Federal Center of Competence, which state the dominance of the process-based approach to change management at the enterprises participating in the national project (Methodical recommendations, 2019). At the same time, the system-based approach preserves its guiding and regulatory impact on business processes, which functioning ensures the implementation of the national project's "Labor productivity and employment support" target parameters at the level of the participating enterprise.

The results of the research can be applied at industrial enterprises in the implementation of labor productivity projects; in centers of excellence, in research and expert organizations - when developing recommendations for improving management activities at enterprises that are carrying out large-scale organizational changes. 


\subsection{Testing and discussing research results}

The proposed integrative management model (Fig. 3) was tested at enterprises participating in the national labor productivity project in Perm Krai. Table 3 (Table 3 ) shows the implementation features of this model's individual elements at 3 large industrial companies that carried out the transformation of activities within the national project in 2019. As can be seen from Table 3 (Table 3), the developed model can be implemented in practice, its implementation leads to positive effects for the enterprise. It should be particularly noted that at the enterprises presented in the sample the main national project's indicator - the annual increase in labor productivity - was several times higher than the established minimum threshold of $5 \%$ (Table 3 ). This became possible due to the synergy effect from integrating the structural elements of management, which previously functioned without interaction, into a single model. Also the enterprises participating in the national project "Labor productivity and employment support" formed an expanded understanding of organizational changes carried out at them.

At the same time, some problems, that need to be addressed, have emerged while introducing an integrative management model at the enterprises of Perm Krai, which were implementing the national labor productivity project in 2018-2019:

1. Employees do not always perceive the development program of the enterprise, which is implemented within the national project, as an element of the general corporate strategy. To solve this problem, it is necessary to involve the key personnel in the development of such a program more actively, as well as explain to employees the relationship between these strategic documents.

2. Inadequate attention is paid to creating the infrastructure which should support innovative transformations within the national project. This problem can be solved by forming network structures for supporting innovation, including project teams, committees, councils for continuous improvement, etc.

3. There is no corporate culture based on the ideas that organization's activities should be improved continuously, which leads to staff pushback. Several measures are proposed to eliminate the problem, they are available for use at an individual enterprise. These measures include forming a group of transformation agents involving at least $2-5 \%$ of the enterprise's average headcount, identifying and supporting system leaders, continuous corporate personnel training, developing an employee's motivation system aimed at achieving the target gain in labor productivity.

Table 3

Test results of model elements integrating system-based and process-based approaches to management at the enterprises participating in the national labor productivity prohect

\begin{tabular}{|c|c|}
\hline Model elements & Transformations and achievements \\
\hline \multicolumn{2}{|r|}{ Perm Chemical Company } \\
\hline Strategy & The main enterprise's development directions are identified at a problem-target seminar \\
\hline Structure & $\begin{array}{c}\text { LEAN concept is taken as a basis, the elements of matrix management structure are introduced, a } \\
\text { project office is created }\end{array}$ \\
\hline Personnel & The personnel received a proactive training, teams are formed to manage development projects \\
\hline $\begin{array}{l}\text { National project } \\
\text { goals }\end{array}$ & $\begin{array}{l}\text { In } 2019 \text { the growth in labor productivity reached 12\%, the company became the leader of TOP-10 } \\
\text { large companies, having taken the first place in the "Export potential" category of "Techup-2019" } \\
\text { national rating }\end{array}$ \\
\hline \multicolumn{2}{|r|}{ Research and production association NPO “Iskra” } \\
\hline
\end{tabular}




\begin{tabular}{|c|c|}
\hline Strategy & $\begin{array}{c}\text { The main enterprise's development directions are identified at a problem-target seminar; the system } \\
\text { of strategic project portfolio management is updated }\end{array}$ \\
\hline Structure & $\begin{array}{l}\text { LEAN concept with the elements of QRM concept is taken as a basis, the elements of matrix and } \\
\text { project management structures are introduced }\end{array}$ \\
\hline Personnel & The personnel received a proactive training, teams are formed to manage development projects \\
\hline $\begin{array}{l}\text { National project } \\
\text { goals }\end{array}$ & In 2019 labor productivity growth reached 36\%, net profit doubled \\
\hline \multicolumn{2}{|r|}{ Perm scientific-industrial instrument making company } \\
\hline Strategy & Revision of strategy with respect to the accepted QRM concept with the elements of Agile one \\
\hline Structure & $\begin{array}{l}\text { The system of project teams and production QRM units is introduced; the production system } \\
\text { development committee is created }\end{array}$ \\
\hline Personnel & $\begin{array}{l}\text { There is a system of continuous staff development, all-Russia conferences devoted to production } \\
\text { systems development are held regularly }\end{array}$ \\
\hline $\begin{array}{l}\text { National project } \\
\text { goals }\end{array}$ & $\begin{array}{l}\text { In } 2019 \text { the labor productivity growth reached 14\%; the enterprise entered the TOP-30 leaders in } \\
\text { labor productivity growth in the instrument-making industry }\end{array}$ \\
\hline
\end{tabular}

Source: authors' elaboration

Despite the noted problems, the proposed model for integrating the system-based and process-based approaches to enterprise management can serve as a basis for improving management at enterprises participating in the national labor productivity project. The model has a universal character, which makes it possible to use this model in the implementation of other large-scale programs and projects related to organizational changes.

\section{Conclusions}

The research results include:

- A model has been developed for the integration of system-based and process-based approaches to the management of industrial enterprises, this model can be used as a basis for improving management while implementing corporate labor productivity projects;

- The new management model was analysed in terms of its impact on the performance parameters of Perm large industrial enterprises participated in the national labor productivity project in 2019. The analysis showed, that the actual increase in labor productivity exceeds significantly the target indicators set within the national project for the individual enterprise, which confirms the validity of the first hypothesis;

- The following conclusion is made: when the system-based and process-based approaches are integrated to enterprise management, this does not only contribute to an increase in the efficiency of industrial enterprises, but also leads to the emergence of specific problems connected to applying this innovation in management practice. Such problems need to be identified and eliminated on time using extensive measures. This means that the second hypothesis of the study was partially confirmed.

The results of the study contribute to the development of the integrative approach methodology, reflecting the integration features of the system-based and process-based approaches to enterprise management in the labor productivity projects. The research results can be used in the Federal and regional centers of competence to develop recommendations for improving management at enterprises participating in the national project "Labor productivity and employment support". The practical application of the research results will increase the 
efficiency of the necessary transformations at individual enterprises, which will positively affect the goals achievement of the labor productivity projects.

\section{Acknowledgments}

The authors gratefully acknowledge the General Director of the public joint-stock company "Perm scientificindustrial instrument making company" Andreev Alexei Guryevich for the valuable advice used when preparing this article.

\section{Bibliographic references}

APQC Process Classification Framework. Retrieved from: https://www.apqc.org/resource-library/resourcelisting/apqc-process-classification-framework-pcf-cross-industry-pcf-1 (accessed September 25, 2019).

Badalov, A. YU., Dudnikov, A. S., \& Trubicyn, S. N. (2011). System-integrative approach in research to manage innovation in integrated telecommunications structures. Scientific papers from Belgorod State University. Series: Economy. Informatics,7, 3-10.

Best, K. (2006). Design Management: Managing Design, Strategy, Process and Implementation (p.215). Lausanne: AVA Academia.

Con, M. (2019). Agile: Evaluation and Project Planning (p. 418). Moscow: Alpina Publisher.

Dolzhenkova, Yu. V., Polevaya, M.V, \& Kamneva, Ye. V. (2019). State and prospects of growth of labor productivity of workers in the framework of the national project «Labor productivity and employment support». Economics. Taxes. Right, 12 (6), 6-16. DOI: 10.26794 / 1999-849X-2019-12-6-6-16

Gokdeniz, I., \& Kartal, C. (2017). Strategic Assessment based on 7S McKinsey Model for a Business by Using Analytic Network Process (ANP). International Journal of Academic Research in Business and Social Sciences, 7 (6), 342-353. DOI: 10.6007/IJARBSS/v7-i6/2967

Hobbs, D.P. (2007). Introducing lean manufacturing: a practical guide to optimizing your business (p. 352). Minsk: Grevtsov Publisher.

Ivanov, O. B., \& Buchwald, E. M. (2019).National projects of Russia: regional dimension. ETAP: Economic theory. Analysis. Practice,1, 37-53.

Kirchmer, M. (2017). High performance through business process management (p. 156).Cham: Springer.

Kostareva, L.V. (2018). Implementation of priority national projects in the Russian Federation: problems and prospects. Society, Economics, Management, 3(1), 37-43.

Methodical recommendations "Attracting consultants to participate in the federal project" Targeted support for increasing labor productivity at enterprises ". Retrieved from: privlechenie_konsultantov_v2\% 20 (2) .pdf (accessed September 25, 2019).

Parfenova, M.Ya. (2013). Methodological aspects of an integrative approach to management based on the convergence of classical approaches. Humanitarian, socio-economic and social sciences: scientific electronic journal, 4, 6-15. Retrieved from: https://www.onlinescience.ru/m/products/economi_sciense/gid607/pg0/) (accessed September 15, 2019).

Passport of the national project "Labor productivity and employment provision". Approved by the Presidium of the Council under the President of the Russian Federation for Strategic Development and National Projects 
on December 24, 2019, Minutes No. 6. Retrieved from: http://government.ru/info/35567/ (accessed September 20, 2019).

Pulakos, E.D. (2009). Performance Management: A New Approach for Driving Business Results (p.214). Chichester: John Wiley \& Sons Ltd.

Radosteva, M. V. (2018). Labor productivity: the main trends and key development factors at the present stage. Economics and management systems management, 29(3-1), 162-172.

Report on the interim results of the expert and analytical event "Analysis of the planning and implementation of activities of the national project" Labor productivity and employment support ", including an assessment of the balance of goals, objectives, indicators, activities and financial resources, as well as its compliance with the long-term goals of socio-economic development of the Russian Federation ". Retrieved from: https://ach.gov.ru/audit-national/ (accessed September 22, 2019).

Rusanovskiy, V.A. \& Markov, V.A. (2017). Employment and Labor Productivity in Macroregions of Russia: Spatial Interdependence. Studies on Russian Economic development, 29 (2), 135-143.

Sherman, D. J., Berkowitz, D., \& Souder, E. W. (2005). New product development performance and the interaction of cross-functional integration and knowledge management. The Journal of Product Innovation Management, 22, 399-411.

Suri, R. (2015). Time is money. Competitive advantage of responsive manufacturing (p. 326). Moscow: BINOM Laboratory of knowledge.

Yu, D., \& Zhou, R.(2017). Intellectual Management: An Integrative Theory. Journal of the Knowledge Economy, 8, 929-956.

Zollo, M., Minoja, M., \& Coda, V. (2018). Toward an integrated theory of strategy. Strategic Management Journal, 39 (6), 1753-1778.

Esta obra está bajo una Licencia Creative Commons Attribución-NoCommercial 4.0 International

(cc) BY-NC 